EJEM

Econ. J. Emerg. Mark.
ECONOMIC JOURNAL OF

EMERGING MARKETS

Available at http://jurnal.uii.ac.id/index.php/jep

\title{
Spin-off and its impact on the third party funds of Indonesian Islamic banking industry
}

\author{
M. Nur Rianto Al Arif ${ }^{1}$ \\ ${ }^{1}$ Faculty of Economics, Universitas Negeri Syarif Hidayatullah, Jakarta, Indonesia. \\ e-mail: agif08@gmail.com
}

Article Info
Article history:
Received : 8 September 2013
Accepted : 10 January 2014
Published: 1 April 2014

Keywords:

spin-off, asset, third-party

fund, regression

JEL Classification:

G21, G29

DOI:

http://dx.doi.org/10.20885/ejem vol6.iss1.art5

\begin{abstract}
The purpose of this paper is to examine the spin-off policy based on Islamic Banking Act No. 21/2008 had an impact on the third party fund of Islamic banking industry in Indonesia. This research used ordinary least square regression consisting dummy variable of spin-off, deposit margin, non-performing financing (NPF), efficiency ratio (BOPO), and profitability ratio (ROA). The result showed that all the independent variables had an impact on the third party funds in Indonesian Islamic banking industry. The implication of this result is spin-off policy had a good impact on the growth of third party funds in Indonesian Islamic banking industry.
\end{abstract}

\begin{abstract}
Abstrak
Tujuan dari makalah ini adalah untuk menguji kebijakan spin-off yang didasarkan pada Undang-Undang Perbankan Syariah No. 21/2008 akan memiliki dampak pada dana pihak ketiga di industri perbankan syariah di Indonesia. Penelitian ini menggunakan teknik regresi Ordinary Least Square yang terdiri dari variabel dummy spin-off, marjin deposito, non-performing financing (NPF), rasio efisiensi (BOPO), dan rasio profitabilitas (ROA). Hasil penelitian menunjukkan bahwa semua variabel independen berdampak pada dana pihak ketiga di industri perbankan syariah Indonesia. Implikasi dari hasil ini adalah kebijakan spin-off memiliki dampak yang baik pada pertumbuhan dana pihak ketiga di industri perbankan syariah Indonesia.
\end{abstract}

\section{Introduction}

The banking sector is the heart of the economic system from the country and part of the object of the government's monetary policy. To determine whether a bank is sound or not, there must be an assessment of the bank performance. To assess the performance of the bank, the bank's financial statements will be required, because the bank's financial ratios can be calculated based on the financial statements to assess the financial condition of the banking in the past, present, and more likely in the future.

The concept of Islamic banking and finance, which was originally just a theoretical discussion, has now been growing and developing. In fact, the current Islamic banking industry has transformed from simply an alternative bank with a sharia bank system into sharia banking industry that is able to play its role in the world economy. Islamic banking and financial institutions continue to experience a significant growth. According to the annual report of the Islamic Development Bank (IDB) in 2009, the Islamic financial institution was expected to grow more than $15 \%$ per year, with a number of Islamic financial institutions is more than 300 spreaded over 75 countries with an estimated total assets of 500 billion dollars, or around 4,600 trillion rupiah. In other words, the market has 
now reached about 10\%. From this IDB report, we can conclude that the industry is still promising a remarkable development in the future.

On July 16, 2008, has passed Law No. 21 of 2008 concerning Islamic Banking. With the passing of this law provides the legal basis and the national Islamic banking industry is expected to encourage the development of Islamic banking industry for the better. One of the crucial issues in this legislation that can accelerate the development of Islamic banking in Indonesia is related to the separation (spin-off) Islamic business units both voluntary and mandatory if the asset of Islamic banking unit has reached $50 \%$ of the parent bank's assets or after 15 years since the Law No. 21 of 2008 had been applied.

After the enactment of Law No. 21 of 2008 appeared a new trend establishment of Islamic banks through the mechanism of acquisition and conversion of conventional banks into Islamic banks. Implementation can be done through three approaches, namely: First, conventional banks that already had a Islamic banking unit acquires a relatively small bank then convert it into a Islamic banks and release as well as incorporating Islamic banking unit with the newly converted bank. Second, conventional banks do not have Islamic banking unit, acquired a relatively small bank and convert it into an Islamic banks. Third, conventional bank separation (spin off) and used as a separate Islamic Banks (Karim, 2008).

According Tubke, et.al (2004) there are several factors that affect the separation process (spin-off). First, the factors associated with the business activity, the first factor is related to the size of the company and the business sector differences between the parent company to its subsidiaries. If the first factor is associated with the Islamic business unit can be positioned as a conventional bank subsidiaries and parent company. Second, the factors associated with the organization and management of the company. Third, factors associated with relationships and support. There are three patterns of relationships that may be created between the parent company with subsidiaries which perform the separation, namely the relationship market (market-Relatedness), the relationship of the product (product Relatedness), and the relationship of technology (technology-Relatedness). Fourth, transfer factor or transfer such transfer of experience from the parent company to its subsidiaries. Fifth, factors associated with motivation. Sixth, the factors associated with the business environment in the form of the characteristics of the regional business environment and legal framework

In the year of $2010-2011$, many of Islamic banking Unit (UUS) decided the spin-off (separate themselves from the Parent Bank) to establish Islamic Banks (BUS), with a reason to promote Islamic banking and more independent management. From 11 Islamic Banks (BUS), who was born purely through the spin-off Islamic banking unit are BJB Syariah and BNI Syariah, while others have appeared Islamic banks through acquisitions, such as the Bank of Syariah Mandiri derived from the acquisition of Bank of Susila Bakti, Bank Mega Syariah of acquisition of Tugu Bank, and BCA Syariah through Bank of Jasa Artha. Moreover, the spin-off through the acquisition then subsequently converted, such as Bank of Syariah Bukopin. BRI Syariah through Bank of UIB, Victoria Bank through Swaguna Bank, Maybank Syariah through Maybank Indocorp. Separation initially considered beautiful, it was not as easy to do, there were Islamic banks that successful in the spin off, but there were also Islamic banks experience some setbacks in spin-offs when becoming Fullpledge Islamic banks.

Spin-off policies that have been implemented in 2008, are still not able to reach the target market share of $5 \%$ of the national banking assets as well as the phe- 
nomenon of Islamic Banks spinoff spinoffs are still not strong visible management of indicators financial performance displayed. Accordingly, this study sought to determine the impact of policy separation (spin off) of Islamic banking Unit (UUS) into Islamic Banks (BUS) to third party funds in the Indonesian Islamic banking industry.

\section{Methods}

To achieve the goal of this research analyzing the influence of spin-off policy on the growth of third party funds of Indonesian Islamic banking, regression analysis is used. The mathematical equation proposed in this research is:

$$
\begin{aligned}
& Y \_t=\beta \_0+\beta \_1 \quad \text { D_t }+\beta \_2 \\
& X \_2 t+\beta \_4 X \_3 t+\beta \_5 \quad X \_4 t+\varepsilon
\end{aligned}
$$

where:

Yt is the third party funds;

Dt is dummy variable for spin-off

Which is: 0 before spin-off, 1 after spinoff;

$\mathrm{X} 1 \mathrm{t}$ is non-performing financing (NPF);

$\mathrm{X} 2 \mathrm{t}$ is one-month deposit margin;

$\mathrm{X} 3 \mathrm{t}=\mathrm{BOPO}$

$\mathrm{X} 4 \mathrm{t}=\mathrm{ROA}$

After processing the regression analysis, to see whether the model is good or bad, we have to know the goodness of fit of the model. To see the goodness of fit of the model, we have to look at the tstatistics, F-statistics, the coefficient of determination (R2), as well as to cover classical assumption test heteroscedasticity, autocorrelation, and multicollinearity.

Decision to accept or reject Ho was made on the basis of the value of the test statistic obtained from the existing data. Under the normality assumption followed the statistical distribution of variable $t$ with degrees of freedom Nk. A statistic is said to be statistically significant if the value of the test statistic is in the critical region. The aim of statistical $t$ test is to see how big the effect of independent variables on the dependent variable individually.

Testing the null hypothesis is with F-statistics is necessary to test if $\beta \mathrm{k}=0$. The calculation of F-statistics performed by comparing the critical value $\mathrm{F}$ obtained from $\mathrm{F}$ distribution table at a certain significance level. If the null hypothesis is rejected, it means that the independent variables affect the dependent variable. In this case, the empirical treatment aims to look at the effect of independent variables on the dependent variable.

The coefficient of determination or R2 is a measure of goodness of fit which explained whether the linear regression is in line with observational data. Kennedy (2008) said the coefficient of determination, R2, to represent the proportion of the variation in the dependent variable explaied by variation in the independent $\mathrm{v}$ ariables. If $\mathrm{R} 2=1$, it means perfect relationship between independent variable and dependent variable, otherwise $\mathrm{R} 2=0$ means no relationship between independent variable and dependent variable.

\section{Result and Discussion}

According to data processing based on Islamic banking statistics, we get the equation from this model as follows:

Third-party funds $=$

$$
\begin{aligned}
& 474538.4+62464.78 \text { D_spinoff } \\
& \text { (8.0741) (2.91402) } \\
& -22656.1 \mathrm{NPF}+\text { 23458.9 Margin } \\
& \text { (-6.94589) (7.28316) } \\
& -1883.82 \mathrm{BOPO}+29811.1 \mathrm{ROA} \\
& (-2.63557)
\end{aligned}
$$

Where:

R2 = 0.81982;

Adj.R2 = 0.80647;

F-statistic $=61.4237$.

From the results obtained above, it is seen that the coefficient of the constant value is 474538.4 , meaning that when all other variables are assumed to be zero; the 
third party funds will still increase every month. Then for the spin-off dummy coefficient, which is zero if the period time before the enforcement of spin-off policy and 1 if the period time after the enforcement of spin-off policy, has a positive sign. It means that there is a positive relationship between the spin-off policy and the increasing of Islamic banking third party funds. The value of t-test shown a significant result implied that there is an effect between spin-off policies based on Law of 21/2008 about Islamic banking to the third party funds growth of Islamic banking industry in Indonesia.

The first control variable is the ratio of NPF in Islamic banks which shown that t-test value is higher than the t-table value; it means that there is a relationship between NPF and third party funds that held by Islamic banks. These results indicate that the health of banks into one of the determinants of customers to save. From these result showed that the increasing of NPF in Islamic banks will decrease the desire of customers to save in Islamic banks.

The second control variable is margin of one-month time deposit which shown that t-test value is higher than the $\mathrm{t}$ table value; it means that there is a relationship between one-month time deposit margin and third party funds that held by Islamic banks. These results indicate that the higher level of one-month time deposit margin, the number of third party funds will increase. These results indicate that the margin of profit-sharing offered by Islamic banks still be one of the determinants of the level of customer savings. These results indicate that customers in Islamic banks are still many who fall into the category of rational customer, where the rate of saving it is determined by the size of the margin has to offer.

The third control variable is efficiency ratio that measured by BOPO. The result showed that there was a relationship between the BOPO ratio and third party funds that held by Islamic banks. These results indicate that the higher level of $\mathrm{BO}-$ PO in Islamic banks, the number of third party funds will decrease. The higher level of BOPO means that the Islamic banks more inefficient, because the operational cost was higher rather than the operational income. This can be caused, that the efficiency level of Islamic banks becomes one of determining in saving decision of customers in Islamic banks.

The fourth control variable is profitability ratio that measured by return on asset (ROA) on Islamic banking industry. The result showed that there was a relationship between the ROA and third party funds that held by Islamic banks. These results indicate that the higher the level of profitability in Islamic banks, the number of third party funds will increase. This can be caused, because of the bank as measured by ROA ratio becomes one of determining how much of the amount of funds to be deposited in Islamic banks.

To see how much this model is influenced by the existing variable, we can use the coefficient of determination. The value of Adj.R2 is 0.806407, explained that the proportion of the variation in the dependent variable explained by variation in the independent variables was 80.64 percent; the rest is explained by other variables outside of the existing models. Next, to see the simultaneous effect of all independent variables to dependent variable used the Fstatistics test. Based on the empirical result shown the F-test value is 61.4237 , it means that the existing variables have an influence on the amount of third party funds contained in Islamic banking.

From this result we can conclude that spin-off policies that applied to Islamic banking industry in Indonesia had a good effect to increase the third party funds. This result give a some result as same as that done by Nasuha (2013). Nasuha done the research about the performance difference on Islamic banking unit that decided to 
spin-off, such as BNI Shariah, BRI Shariah, BJB Shariah, BSB and Victoria Shariah. The research is done by Wilcoxon Match Pairs test that saw the performance between before and after the spin-off decision on Islamic banking units. The variables of Islamic banks performance are asset, financing, third party funds, net earnings, CAR, NPF, FDR, ROA and ROE. The result shown that only asset, financing and third party funds that shown a difference between before and after spin-off policies on that five banks. Otherwise for other variables such as CAR, FDR, ROA and ROE shown that there were no difference on CAR, FDR, ROA and ROE in Islamic banks. This result might be due to the spinoff is new practiced in the Islamic banking industry, so the testing period was short on this research.

Beeson and Hyden (2002) stated that if a lot of company done the spin-off to increase the competitiveness of the company and create the value for the shareholders by focused on it primary business. Christo and Falk (2006) showed that the key factor of spin-off is the focused of the industry. From these result and we related to this research, we can stated that the spin-off decision that had been done by several Islamic banking unit can give a value for the parents company and also for the shareholders. Because the parents company can focused on his primary business, and the subsidiary company can focused to develop.

Veld and Veld Merkoulova (2002) doing the research in 156 spin-off in Europe since 1987 until September 2000, the result showed that there is an increasing of abnormal earning is about $3.57 \%$ for company that focused on its core business, and only $0.76 \%$ for company that not focused on its core business. Herzeca (1996) stated that spin-off has been successfully used to facilitate the achievement of our strategic objectives with as allow it to focus on its core business. Herzeca further argued that the spin-off has been able to effectively separate the business capital of the businesses that have high growth. In addition to the spin-off can eliminate the conflicts that exist in two different businesses.

Agarwal et.al (2004) suggested that the separation is often formed to capitalize on the knowledge that is created by their parent company but not exploited. This explains why the company better, may create more knowledge, but it may have a higher level of separation. This model explains the reason for separation as to develop knowledge of the less exploited by its parent company. This model shows how the separation (spin-off) provides a mechanism to compensate for ability limitation of companies to evaluate new ideas.

From the results obtained, then associated with several previous studies showed that the spin-off policy has a good influence on the development of the industry. This is similar to the case of the spinoff policy in the Islamic banking industry in Indonesia, where the spin-off policy proved to increase the growth of third party funds itthe Islamic banking industry.

\section{Conclusion}

Spin-off policy as contained in the Law 21 in 2008 is one of the breakthroughs that aims to accelerate the growth of Islamic banking in Indonesia. It is intended that Islamic banking is able to independently develop its operations, independent of the parent bank which still operates conventionally. The model proposed in this study uses regression with a dummy variable, as well as control variables in the form of internal factors such as the NPF, margin, and ROA. The results showed that all the independent variables give a significant influence on the growth of Indonesian Islamic banking industry. So, we can conclude that the spin-off policies have a significant impact on the growth of third party funds in the Indonesian Islamic banking industry.

The empirical results obtained in this study indicate that the spin-off policy 
pursued by the government to accelerate the growth of Islamic banking in Indonesia is right. It is shown that the spin-off policy is able to increase the growth of third party funds in the Islamic banking industry in Indonesia. The results of this study also helped to support the studies of spin-offs that show a positive influence on the development of the company.

The model in this study still needs to be improved, because the data used in this study used data Indonesian Islamic banking industry in general. Therefore it is recommended for future research may use data derived from each Islamic banking unit who have decided spin-off into Islamic banks. It is intended that the analysis obtained more sharp and accurate in giving an overview of the effect of the spin-off policy towards the Islamic banking.

\section{Reference}

Agarwal, R., R. Echambadi, A.M. Franco, M.B. Sarkar (2004), "Knowledge Transfer through Inheritance: Spinout Generation, Development and Survival", Academy of Management Journal, 47(4), 501-522.

Karim (2008), "Kajian Pemisahan Unit Perbankan Syariah,", http://karimconsulting.com/category /kajian/, accessed on 18 December 2013, 17:00, West Indonesia Time

Beeson, J. and C. Hyden (2002), "Corporate Spin-offs: Gaining Focus and Unleashing Stockholder Value," Orange County Business Journal, (39), 14-25.

Cristo, D.A. \& R.W. Falk. 2006, "Spinoffs and Carveouts: Some Factors Leading to Successful Divestiture," Competition Forum, 4(2), 331-347.

Herzeca, L. (1996), "Spin-offs: The Latest Divestitute," Fad. Best's Review, 97(4), 65.

Nasuha, A. (2012), "Dampak Kebijakan Spin-off Terhadap Kinerja Bank Syariah," Jurnal Iqtishad, 4(2), 241258.

Tubke, A., P.A.T. Saavedra, and J.G. Gonzalez (2004), "Towards a First Spin-off Typology and a New Concept for Corporate Spin-off Research," International Journal of Technology Transfer and Commercialization, 3(3), 263-290

Veld, C. and Y.V.Veld-Merkoulova (2004), "Do Spin-offs Really Create Value? The European Case," Journal of Banking and Finance, 28(5), 11111135 